\title{
Gay science: assisted reproductive technologies and the sexual orientation of children
}

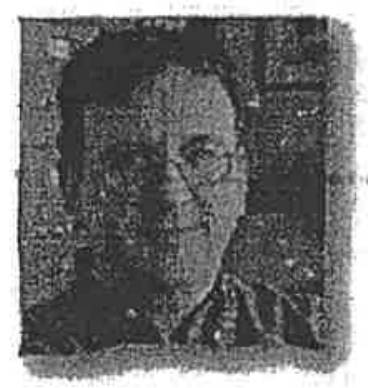

Timothy F Murphy

Tim Murphy first studied Philosophy as an undergraduate at LeMoyne College, New York, going on to take graduate degrees in the subject at Boston College. Currently he is Professor of Philosophy in the Blomedical Sciences and is a member of the Graduate Faculty, in the Department of Medical Education at the University of Illinois College of Medicine, Chicago, Illinois, USA. From 1998 to 2001 he was Principal Investigator on the NIH project 'Research Ethics in Clinical, Biomedical and Public Health Sciences'. He is the author of several books and many peer-reviewed articles.

Department of Medlcal Education m/c 591, Universtty of Illinois College of Medicine at Chicago; B08 South Wood Streat, Chicago IL 60612-7.309, USA

Correspondence: $\theta-$ riail: tmüphyouic.ëdu

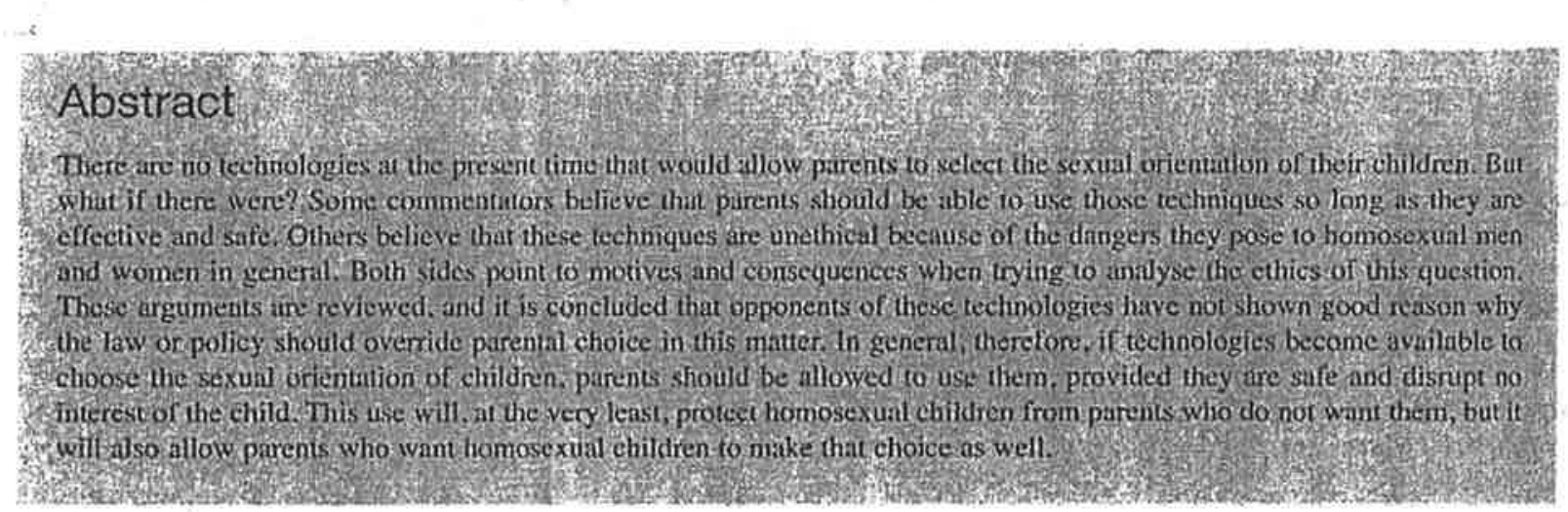

Keywonds: assisted reprodictive xectinologies, chlldren. homosexualiby, parents, law

\section{Introduction}

Parents use a variety of folk practices to influence the onits of their ehildren, even before they are borm. Some would-be parents engage in intercourse in various pasitians or at certain times of day or come to sexual climux in a particular order in the belief that doing so will give them a child of a preferred sex. While many parents have strong interests in the sexual orientation of their children, it is not:clear that that they have developed folk practices 10 influence that outcome prior to birth. Because of advances in biological study. however. prenntul tests and interventions for sexual orientation are one of the topics-in-chjef when it comes to the scientific study of homosexuality (Murphy, 1997).

In 1979, philosopher' Lawrence Crocker (Crocks., 1979) wrote the first sustained ethical analysis of using a prenatal intervention to control the sexual orientation of children. Then, as now, the discussion was entirely speculative, as there are no known interventions of this kind. Crocker called the attempt to control sexual orientation 'meddling', but he nevertheless outlined a strong defence of parents" rights to use a "rntigic pill" that could be taken during prognancy to ensure beterosexuul children. Crocker used the following assumptions to come to that conclusion: that heterosexulity in children is better than tiomosexuality for children, their farnilies, and society at large: that homosexuad men and women are significantly unhappier than heterosexual men and women; and that no amount of social transformation will materially alter these facts. Crocker does call these assumptions fur-fetched, but he offers no other view of homosexuality when concluding that panents would be within their rights to use a magic pill, so long as the pill was completely effective and safe. In faet, Crocker's argument extends much further than he appreciated. If homosexuality were as objectionable as he said. one would really have to conclude that parents would be morally deficient if they had nccess to this pill and did not use it (Murpty. 1997. pp. 110-111). Not using such a magie pill would violate a parent's prima facie detity to avoid exposing their children in serious and awadtable harm. If homosexuality ouce only half us bad as Crocker says, his views really might be the last word on the topic, but the matter is more complex than his highly contentious assumptions allow. 
Crocker's 1979 article occurred in the context of the work of Bell and Weinberg, one of the most importani studies of sexulul behaviour in the United States (Bell and Wemborg, 197.8). In the psychedelic 1970s, talk of mngic pills was vory much in the air. Among ottier things. for exumple, Bell and Weinberg asked their hamosexual subjects whether they would bave preferred a magie pill at birth to guamantec their heterosexiallty. Most homosexual men and women rejected this medicated rewriting of their lives, 72-89\%, depending on sex und race (Bell and Weinberg, 1978, pp. 124, 339). An even larger majority said they would reject a pill that would change their sexual orientation now, in adulthood, 86-95\%, aguin depending on sex and race. It should be mentioned, though, that some of these same subjects said they would be upset or somewhat upset if a child of theirs were to become homosexual $25-33 \%$, depending on sex and race. Most subjects in this study did not want their own sexual orientation changed, but a significant number would not want to see their own children become homosexual, Bell and Weinbery did not ask the subjects why they felt that way. This unanswered question shadown discussions about controlling the sexual orientation of children to this day.

The Bell and Weínberg study is dated, of course. by decudes of social change regarding the status of homosexual men and women, not the least of which has been the declassification of homosexality as pathological by modical organizations (Bayer, 1987). Even the venerable Uaited States Supreme Court has reversed course and caught up with the 1957 Wolfenden Report (sec The Wolfenden Roport, 1963) and the 1804 Napolooritic Code before thut. In 1986, the court said in Bowers: $y$. Hardwick that it was perfectly constitutional for states to oriminalize sodomy, raying they had moral and logel history on their side. In 2003, the Court repudiated this and said that states could not criminalize private and consensual sex between adults of the same sex, so long as no moncy was changing hands (Greenhouse, 2003). Clearly a lot had changed in thoso intervening 17 years. The thereased social accoptanoc of honioseruality would probably leud teven [ewer homuscxua] men and women to say today that they would be upset if their child shared their sexusl orientation. No researchers have asked this question for a while, so we can't bo sure, but the pendultum might even have swung the other way, to the point that some parants - homosexual and heremsexual allike might actively wish to bave homosexual children, an option that Bell and Welnberg did not even think to ask about, sucli were the times.

\section{Motives for avoiding having homosexual children}

To be sure, not all parents are sanguine about the prospect of having hornosexual children. and there seern to be two main rationales: why parents would want only heterosexual children. The first rationale is rooted in a belicf that that heterasexuality. is in the child's better intenest, elther as something inherently valuable or as instrumestally valuable. Whether they think of hamosexunlity as antithetical to human nature itself, or whether they think of it merely as a handicap in an overwhielmingly heterosexual world, sorne purents genuinely believe that heterosexpality is ultimately more valuable than bornosexuality to children. But is this alwsys me? There are, of course, unhappy homoscxual men nnd women, but it iș hardly true across the bound thas bomosexuality must be an obstacle to meaningful human life. Some of the unhuppiness ascribed to bomosexuality can be traced to differential social treatment, in schools, for example, that pretend that homosexual adolescents and their particular needs and interests do not exist (I!lingwort)] and Murphy. 2004). Yet most homosexual people mound the globe find their way to ample measures of hope, love, and happiness. In any case, parents are not always perfectly situated to know what traits will best serve the interests of their clrildren in the long run, whether in inatters of intelligence, sex, or sexual orientation. Consequently, the view that parents act beneficently toward their children only if they toy to ensure their heterosexudity is far from persuasive.

The second rationale for preferring to have heterosexual children is reoted in the desira to liave children who conform to parents' expectations. Some men and wornen might want to avoid gag and lestian children to avoid the perception that they have been poor parents whose behaviour is causally implicated in the emergence of their children's hamosexuality. that they have been smoiherifig mothers or emotionally distant fathers. Some parents object to homosexuality on religious or moral grounds and siniply do not want their children involved In that - as they see it - objectionnble behaviour, Other parents might hold no particular moral or religious objection to homosexuality but simply find it alien to their own experienco: they doubt they can offer homosexual children the kind of special care and attention they might need. There is an episternological problem here, of course, because parents cannot know in advance bow they will see their children in the future or bow their views will change because of thoir children. Many parents do love, nurture, and take delight in their homosexual children, their prior scruples and demurrals nowithstnoding. It is not obvious therefore that sexunl orientation must be an impediment to mutually rewurding parent-child relationshipis: parents can love, nurture, and teach their children, and children can returin those fayours in the ways they are able, regardless of sexual orientation. Even if parenis and children do not ultimately share the same sexual perspectives, the relevant philasophical question here is why and to what extent a child must conform to purental expectation in order to be wanted, loved, and nurtured. Why should a child's welfare ultimately rest on the way in which he or she measures up to parents idealized conceptions of the children they beliove they deserve?

\section{The process of avoiding having homosexual children}

Commentutors writing about prenatul tests and interventions for sexual orientation do not typically focus on the ethies of the interventions themselves, though in some wnys these can be morally problematic. One possible moral objection to teats and interventions is that they overneach the purposes of medicine and health care: helping parents have a child of a particular sexual orientition involves no tredunent of a disense or disorder. But this objection confines the purposes of health care ton closely. Biocthicist Edgar Daht has rightly pointed out that the uses of biomedicine extend well beyond the diagnosis and ereatment of disease properly speuking, so that unless we are willing to mithlessly: prunc many other services from bealth care. this objection carries virtually no weight at all (Duhl. 
2003). Biomedicine can legitimataly focus on human wellbeing rother than health and discase narrowly defined.

What about the actual processes involved? Do they pose any ethical concerns? Prenatal tests for sexual orientation should not expose embryos ar fetuses to unreasonablo risks , and any lest that did would be morally probleniatic in terms of a future child's health. it's not clear, however, thint taking genetic samples from embryos or fetuse must necessarily involvo an unacceptible level of risk, as various kinds of cimbryo biopsy and fetal evaluation have shown. Tests would also be morally problomutic if they offered false assurancos about the soxual orientation of future cliildren, and people made their choices on the boisis of unreliable information. At the very least, tests should also be capable of delivering what they in fact promise: numcly the acçurate identification of the likely sexual orientation of a child that develops from an enibryo or feruses. Prenutal interventions to influeace sexual orientation of chilinen - thtorventions such as hormone treatinents or genetic treatment - would alṣo have to pass thresholds of both safety and efficacy in order to be morally dofengible, and so long as they did, any monal abjection to them op those graunds would simply wither away.

Beyond questions of safety and efficacy, some commentutors sce cortain interventions an problematic in themselves. For example, if there is only a test for 'gay genes' and no corresponding generic intervention to influence. sexual orientution, parents might discard embryos having the gones they don't like or terminato pregnancies for the same reason. People who oppose the clinical cteation and discarding of embryos under any circumistances would have to decline any sexunl orientation controls that involved these techniques, if they wanted to be inorally consistent, that is. People categrarically opposed to alortion would probably be better off not having fetuses tested for sexual orientation, or they might find themselves unable to act on iuformation they find distressing, if they want to be morally consistent in their views about abortion.

More laissez-[aire views would, of course, allow parents the right to usc cmbryo sclection and abortion in order to avoid having children of unwanted sexual orientacion. Yct some commentators think this goes too far, these commentators do not necessarily object to emibryo discanding or abortion in principle but do not like the gritty prospect of selecting aguinst otherwise healthy embryos and feruses simply to avoid homosexual children. A policy or legal barricr aguinst these uscs of cmbryo selection and abortion in thosc instanocs would be problematic. hovever. because of its idiosyncratic application. Suciety and the law do nor elscwhere supervise the decisions by which purents come to choose the embryos they use for implantation, or terminatc tle pregnancics they are unwilling to continue. Before nny kind of social burrier could be raised against these practices, one renlly would have to show that there is something especiully objectionuble ubout selecting against embryos and fetuses likoly to become homosexinl people. For that kind of argument, most people usually turn away from un evaluntion of the techniques involved to a consideration of their social effects.

\section{The effects of sexual orientation tests and interventions}

Some commentators bave arglued that prenatal tests and interventions for sexual orientation pose dangers to homosexual men and women as a class, Philosopher. Edward Stein identifies tliree aspects of this danger: the use of: methods to solect sexual orientation, their mero availability and oven simply claiming that such methods exist. He says these throo aspects of sexual orientation controls will perpetuate and perhaps amplify the negative conditions faced by lesbians, gay men, and bisextials' (Stein, 1999, p. 327). He says further that "A person who makes use of such u procedure to ensure that a child is heterosexual perpetuates the negative conditions of lesbians, gay men, and bisexuals in this society. This implies that making use of orientation-sclection procedures is morally problematic; all else being equal, given the inupact of such procedures, a person ought not to make use of them' (Sleill. 1999 . p. 320).

Stein sets the moral threshold this way: people have a moral obligation to avoid behaviour that perpetuates of amplifies 'nogativo condicions' for homosexual and bisexual people, but when it comes 10 prenatal interventions this threshold is at once too stringent and too nebulous. It is too stringent trecause there are lots of limis when all else is not equal, In other words. parents might choose heterosexual children for reasons that do not involve hostile views of homosexuality per se. So long as these matters are speculative, thene is no reason to think that the rests could orily be used against homosexual children. Why would that chaice make things worse for homosexual and bisexual people? Stein's threshold is too nebulous because the term "negative conditions" is simply too vague to be in maningful criterion for evaluating such things as the social effects of beliofs about sexunl orientatinn treatments. Just exactly how would the claim that sexual orientation controls exist - simply that they exist, whether they do or don't - make things worse for toinosexual and bisexual people as a class? Do claims like this actually make things worse? Not for any reason Stein puts into evidence. These ane empirical issucs and not matters for armchuir philosophy to decide, not cven computer-axsisted yumchait phílesophy.

In a reluted line of argument, philosopher Linda Barclay has said that 'enginecring someone to have non-gay genes sends a clcar mossage to that person regarding his parent's attitudes to the worth of homosexuality' (Barclay, 2003). She believes that the force of this message works against a child's autonomous judgement about the value and meaning of homosexuality. In other words, the parencs usurp the child's powers of judgement througls genetic enginecring, In fact, however, Barclay assumes an a:ll-too-casy reductionism between parental intent and childhood outlook: children sometimes fall very far from their parevital trees in regard to beliefs and bchaviour. their parents' marnl messages notwithstanding. Even if genctic engineering keeps children from homoerotic desires, it does not follow that they will never engage in homoscxual behaviour or that they will disvalue gay people as a class. For example. many parents now take certain genetic steps to nvoid disabilitics in their children. without their choices nlso inipeding social progress lifthe accominodntion of disabled people. Barclay also overlooks the way in which the same technologies that would allow parents $10 \mathrm{select}$ against 
homosexual children mighi enable parents to choose homosexual children, a choice that would also undereut the view that genetic technologies work only to the detriment of homosexual people.

Commentators like Stein and Barclay have not shown that the social effects of prenatgel sexual arientation fechniques are of a magnitude that justifies an nverriding of parentul choice in regard to the kind of childron they want in have. It is not always objectionable to want heterosexund children; and it does not follow as a matter of either logic or politics that parents. cloices in this regard are incompatible with an increasingly robust social Hecorimotation and piatection of bomosexual men nud women (Dahl, 2003).

\section{The rights and responsibilities of parents}

Despite much effort to find them, researchers have not found definitive biological markers for sexual oriencation or fully identified the biological pathways of sexual development (LeVay, 1991; Hall and Kimura, 1994; Lippa. 2003: McFadden arid Pasanen, 1998; Rahman a al, 2003). In part. that oulcame is prediclable because human wuxunlity is fluid in ways that do not permit cleaving people into biologically distinct sexull orioncations. Partly for this reason, quastions about prenatal control over sexual orientation renjain speculative. Even if there are genouic components to sexual orientution that dispose some people one way or the other, it is unjikely that there will be any simple one-on-one correspondence between genes and sexual orientation, let alone actual behaviour. Too much happens between conception and organm to think thut human sexuality follows any unulteruble genetic trajectory. Some commentators dislike speculation about these mutters, suying that it feeds the very trouble homosexual uien and wotrien fuce. But these quentions - even if speculative - have an intellectual integrity of their own because they help plumb questions about the extent to which children are properly the objects of parental formation.

It is true that some parents will have objectionable and indefensiblo motives for waxting to avoid having homosexual children. It is also ture that the process of contralling sexual orientation in children could involve objectionable methods. such ws selective terminalions, risks of exporimentation, or worrisome und risky genetic manipulations. Moreover, the use of Bexual orientation techniques might ulter the social circumstances of gay men and lesbluns in some ways, ruducing the number of men and women who identify that way, for example. The philosophical question at hand reranins whether. these problematic motives, processes, or social effects rise to a threshold thit justifies state intrusion by law, or policy agninst. the use of prenutal tests or interventions for sexual orientation.

Parents wish to confer udvanlages on their children, and they will do so through the means axailable to them and in light of: their own views about what counts us an advantage. Parents make mistakes. of course, ubout whet is best for their children, but society should generally refrain from intervening against parental choices in this matter. There are better ways to protect homosoxual people and their prior adolescent selves than to monitor and interfere with purents' choices ubout what kind of children they will have. Improving the social and: Jegal standing of gay men and lesbians will ultimately do more to protect them than putuing certain lests and limitations off limits to their parents will. Ferr one thing, parents" resistance to gay and lesbinn children would dissolve to the extent that diey had fewer worries abour their secial fate, if they knew that their children could live in safety and respect. There is special reason to be concerned that social or legal bans on sexual orientation tests and intervencions would endanger the wellbcing of homosexual children bom into families who do not want then. What exactly will be the fate of homosexual children borm in families that would have selected against them except for a social policy or law forbidding them to do so? So far, most critics of sexual orienlation interventions have not looked this question squarely in the eye; but I believe that the potertial for damage to those mosi directly affected - the children - should be the key consideration when deciding about soxial or legal prohibitions in this area.

While the discussion about prenatal interventions teads to twell on its use by parents to ensure the heterosexuality of their children: some paronts will choose the other way: Is there any reason why parents shouldn't be able to make this choice? Pbilosopher Julim Savulescur recommends that would-be purents observe the "principle of procreative beneficence" when choosing among passible childien. Savulescu believes would-be parents should select the childnen they. expect to have the best lives possible, to the extent they can make that determination relative to available lests and knowledge (Stuvulescu, 2001). There is nothing in this principle, however, that categurically forbids parents from choosing to have homosexual children. Sonte parents - armed with strong moral conviction - will certainly imagine that among the best children they can have there is room for a homosexual son or daughter. What is ultimutely important is - as Savulescu points out - that parrents make choices that do not obstruct their children's eapacities to form und act on their own conception of a good life; in which wisdom and pleasure are generously mixod. (I believe Savulescu overstales the meaning of his principle of procreative benoficence. The standard of welltheing he describes us uppropriate for children cerninly does not require the Panglossian requirement that parents choase only the best of all possibile children, only that parents choose traits that do not - all things considered - obstract a child's capacity for a good life, When it comes to these capacities, the lives of homosexunl children are. in principle, as good as the lives of any other children.

In the end, we would do well to hecd the crounsel of philosopher Mary Wamock who has said that 'it seems to me to be a fundumental moral principle that we ought to love and cherish our children as beings separate from ourselves and with their ows distinct characteristics' (Warnock, 1991). 'This counsel is relevanit, certainly, us parents contemplate the use of prenatal technologies, but if is also relevant to children who already exist. The social science literuture is silent on any folk practices parents use to imfluence the sexual orientation of children before they are borw, but parents do strongly try to influence the sexuality of their actual children as they grow up. Mostly they do this by trying to conform children's behaviour to accepted gender noms, sometimes at great cmotional cxpense to children who defy their purents' expectations. The harsh and bullying ways of parents who badger their children towurd gender confomity deserve us least as much ethical 
atlention as the hypothetical question of whether parents are entitled to use prenatal techulogies in their quest for the perfect child, and that remeins true, no matter how far science goes in describing the origins of honosexullty or in offering parents control over the traits of their children.

\section{References}

Barcliyy L 2003 Genetic engineering and aulonomous agency. Journat of dpplied Philosinghy 20. 223-236.

Bayer R 1987 Homosexnaling and Amerkan Pryehiatry, 2nd cdn. Princeton University Press. Princeton, New Jersey.

Bell AP. Weinterg MS 1978 Hemuswexualities: a Study of Diversing Among. Men and Women. Simon and Schusicr. New York.

Crosker $C$ 1979. Meddling with the sexual orientotion of children. In $\mathrm{O}^{\circ}$ Ncill O (ed.) Huving Childron: Philessuphical and I Psyal Reflections on Paremhinod. Oxford University Press. Now York.

Duhl E 2003 Ellical issues in new uses of preimplantation genetic diagnosis, /tuman Reproduction 18, 1368-1369.

Greenhouse $L$, 2(6): Justices, 6. 3. legolize gay sexual cenduct in sweeping reversal of coum's '86 ruling. New hork Times. 7 June $2003 . \mathrm{Al}$.

Hall JAY, Kinura D IW Ded Dermatoglyphic assymetry und sexual orientation in men. Behntiural Neturoscience 108, 1203-1206.

Illingworth P. Murplyy TF 20033 In uur best incerest: meeting the cducational needs of leshian and gay sfudents. Joumol of Social Plithosiphy 35. 198-210.
LeVay $S 1991 \AA$ difference in hypothalanic structure between helcrosexual and homosexual men. Srinuce 253, 10.4-10,3\%

lippa RA 2(K)3 Are 2D/4D linger length ratins nolated to st:xuil oricutation? Yes tor men, no for women. fourmal of Perrismdify and Social Pryotology 85.179-188.

McFadden D. Pasanen EO 1998 Comparisan of the auditory systems of heterosexuuls and homnsexuals: elick-(woked otoacoustic

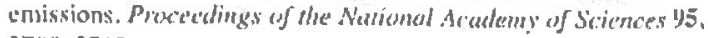
27(109-2713.

Murphy TF 1927 Gun Srience: the Elhics of Sertual Oricunuiom Resererch. Columbia University Press, New York.

Ruluuan Q. Kumari V. Wilson GD 2003 Sexual orientation-redated differences in prepulse inhibition of the human starle respouse. Behavioral Nouroscicne 117. $1(1)$ t -11 ) 2 .

Suvulestiu d 200) Procrative heneficence: why us should setect die best children. Hineshics: 15, 413-426.

Stein E 1999 The Mismeasure of Desire: the Sivenre, Theory, and Bithies of Serual Orientation. Oxford L'niversity Plesy, New York.

The Wollenden Repon 1963 Report of the Commitrec on. Homosexural Ofjences and Prostrutuon. Sicin and Dny, New York. USA [UK govenument repurt. origimally published 10,57.

Wamoxk M IOAI The Uives of Philosophy. Basil Blackwell. Oxford UK.

Receried 11 Octuber 2004 ; referced and accepted 4 Nowember 20104. 